\title{
MAINTAINING MARKET POSITION: TEAM PERFORMANCE, REVENUE AND WAGE EXPENDITURE IN THE ENGLISH PREMIER LEAGUE
}

\author{
Fiona Carmichael, ${ }^{*}$ Ian McHale $\dagger$ and Dennis Thomas $\ddagger$ \\ *Birmingham Business School, University of Birmingham, UK, \\ $\dagger$ Salford Business School, University of Salford, UK, and $\ddagger$ School of \\ Management and Business, Aberystwyth University, Aberystwyth, \\ Ceredigion, UK
}

\begin{abstract}
This paper investigates the relationship between playing success and commercial success in team sports. Utilizing a data set relating to the English Premier League that combines both financial measures and indicators of playing skills and performances, our empirical analysis is based on three behavioural equations. Our analysis indicates that on-field success can be directly related to players' skills and abilities and that revenue is positively related to on-field success. Wage expenditure is also shown to systematically reflect player skills and performances. One interpretation of this evidence is that investment in players' skills and ability buys on-field success, with richer teams becoming ever richer and able to maintain or even build upon success by spending more on players than less successful clubs. To the extent that richer clubs are successful in their objective there is a causal link between revenue earned and competitive imbalance via investments in players. The implications of this tendency within a league are discussed in our conclusion, which also considers the potentially
\end{abstract}

Correspondence: Dennis Thomas, Reader in Economics, School of Management and Business, University of Wales Aberystwyth, Aberystwyth, Ceredigion SY23 3DD, UK. Tel: + 44-(0)1970-628780; Fax: + 44-(0)1970-622740; Email: det@aber.ac.uk. 
wider implications of our study as they relate to the evolution of firm size and issues of market share.

Keywords: competitive balance, hedonic wages, human capital investment, production functions, team sports

JEL classification codes: D2, J3, J4, L1, L2

\section{INTRODUCTION}

This paper combines two research strands in the economics of sport, and more specifically the analysis of association football, in order to investigate the relationship between playing success and commercial success in sporting enterprises. It also examines the possibility of feedback effects from playing success to competitive balance in sporting leagues via the investments of clubs in human capital, i.e., their players. These relationships are explored in the specific context of English Premier League (PL) football, employing an empirical model based on three behavioural equations, with the results appearing consistent with the persistence over time of inequalities between clubs in terms of their playing success and wealth. The ensuing interpretation of how clubs can maintain their place, or enhance their performance, within a league can also lead to insights about how firms maintain or increase their market share.

The next section provides a summary of relevant previous research in the area. This is followed by a description of the study context. We then describe our data set and present the behavioural equations that underly our empirical model. The penultimate section contains an analysis of the results of the estimation procedure. Our concluding section provides a summary and discusses the wider implications of the analysis.

\section{PREVIOUS RESEARCH}

Following Scully's (1974) seminal work there has been a persistent tradition of production function analysis in the economics of sports where teams, like other enterprises, are assumed to be involved in a production process with 'output', in terms of sporting success, arising from the combination of a range of various player and non-player inputs. One strand of empirical research explores the relationships between playing performance and playing success, either in terms of seasonal/tournament outcomes or match results (e.g., most recently, Hofler and Payne, 1998; Carmichael et al., 2000, 2001; Espitier-Escuer and Garcia-Cebrian, 2004; Barros and Leach, 2006a, b; Gerrard, 2006; Hofler and Payne, 
2006), ${ }^{1}$ where output is traditionally measured by such indicators as league position, win rates, points achieved or, in association football, goals or goal difference. Teams' playing performances are measured by indicators of players' skills and abilities (relative to opponents), together with other characteristics, such as age and experience, and non-playing inputs have traditionally included aspects such as squad size and managerial skills. Those studies that have explicitly focused on the physical linkage relationships between measures of playing skills and performance and success on the field of play have modelled the contribution of different player skills and abilities by relating output to a range of different aspects of match play performance. In association football these have included measures of attacking or constructive play (e.g., goals, shots), other constructive play (e.g. passes completed), less constructive play (e.g., dribbles, passes not completed), aggressive play (e.g., tackles) and defensive play (e.g., saves). In addition, those non playing inputs that have been employed include attempts to quantify the influences of home advantage (e.g., Carmichael and Thomas, 2005), managerial/coaching contributions ${ }^{2}$ and team fixed effects, with acknowledgement also made to the chance/stochastic element involved in determining individual match results.

The second strand of empirical research in this area involves a related literature that has explored the relationship between wage/salary expenditure and sporting success (the win-wage relationship) in an effort to identify a causal link between club revenue disparities, and/or withinteam payroll/salary inequalities, and team productivity and performance (e.g., Szymanski and Smith, 1997; Szymanski and Kuypers, 1999; Hall et al., 2002; DeBrock et al., 2004; Dobson and Goddard, 2004; Forrest and Simmons, 2004; Jewell and Molina, 2004). This literature also ties into the competitive balance debate by relating wages and revenue to success. While the evidence is somewhat variable the results of applied research in this area generally indicates a positive relationship between playing success and both wage expenditure and revenue. These relationships have been taken to imply that there is potentially a causal link via wage expenditure from revenue inequality to competitive imbalance between teams in a league. However, the underlying relationship

\footnotetext{
${ }^{1}$ Scully's (1974) model was subjected to various re-specifications and re-estimations, focusing almost entirely on US sports, and Scully (1989) himself updated his original model. See Scully (1995), Downward and Dawson (2000) and Dobson and Goddard (2001, with particular regard to association football) for detailed surveys of production function studies, together with Borland (2006).

${ }^{2}$ Team management and coaching/support staff can directly affect the outcome of individual matches, and eventual seasonal outcomes, through decisions regarding team selection and tactics, within-game substitutions, purchase and sale of players to reconstitute squads, as well as developing teamwork, cohesiveness and morale. Studies incorporating managerial input and efficiency aspects include Porter and Scully (1982), Kahn (1993a), Fizel and D'Itri (1997), Kahane (2005), Hofler and Payne (2006) for US sports, with Dawson et al. (2000a, b) and Dawson and Dobson (2002) specifically treating association football.
} 
between playing performance and wages which presumably underlies the relationship between wages and success has not been explored in this literature mainly due to data limitations. At the same time, links between playing success and financial measures (such as wage costs and revenue) have not been developed in the production function literature (although some studies have estimated cost functions and Gerrard (2006) examines links between the win-wage relationship and a vector of player characteristics such as age and experience).

Informed and motivated by previous work this paper attempts to develop, and explicitly bridge the gaps between, the two strands of research by utilizing a data set that contains both financial measures and indicators of playing skills and performances. The empirical model specifies a production function, a revenue function, and a hedonic wageprice function. We then test the hypothesis that wages impact directly on league success by estimating a production function that includes as independent variables the predicted wage from the hedonic wage estimation and a direct measure of wage expenditure. The analysis indicates that, in line with standard theoretical relationships, output in the English PL (measured by league success) depends on the quantity and quality of playing inputs (i.e., the human capital invested in players). Revenue shares are, in turn, positively related to higher output, investments in human capital (players) are related positively to increases in revenue, and wages are systematically linked to playing skills and performances. In addition, premium wages paid over and above average payments for playing skills and performance appear to be positively linked to success in the league. These linkages are consistent with a causal link between playing success and the maintenance of competitive imbalance via higher revenue, increases in wage expenditure and, consequently, increased availability of playing talent. However, such linkages do not necessarily imply that sustained success by one or more clubs over a number of seasons will lead to increased imbalance. This will depend on the parameters of the model which are explored.

\section{THE ENGLISH PREMIER LEAGUE}

The English PL, also known as the Premiership, forms the top tier of England's professional football structure. It was established in 1992 to replace the First Division of the then four division English Football League (FL), and is regulated by the Football Association (FA) and run separately from the remaining three divisions comprising the FL. The PL and the top division of the FL are linked by the traditional system of end of season promotion and relegation, whereby the bottom three PL clubs are demoted and replaced by three FL clubs. End of season PL positions are determined by accumulated match points over regular 
season fixtures ( 3 for a win, 1 for a draw, and 0 for a loss), with teams equal on total points ranked by aggregate goal difference. While the team topping the PL is crowned 'champion' and qualifies for the following season's European UEFA Champions League competition, a number of other highly placed clubs also qualify for European competitions, along with the winners of two domestic knock-out cup tournaments played alongside PL fixtures. ${ }^{3}$

Although all PL clubs theoretically compete on an equal footing, their aspiration levels and performance capability (not necessarily matched) are variable, depending on financial strength, support base and, in many cases, footballing history. While a small group of clubs are perennial contenders for championship honours and qualification for lucrative European competition, some are fringe candidates for the latter with the majority viewing continuing PL survival as their priority, at least in the short term. Avoidance of relegation, and its potentially dire financial consequences, is a critical consideration, and the end-of-season 'subcompetition' between threatened clubs is commonly as intense and high profile as that involving the leading clubs at the top end of the league table.

During the study period, covering the seasons 1998-1999 to 2004 2005, the English PL comprised 20 clubs, playing each other on a home and away basis, whose composition varied from season to season due to the system of promotion and relegation (usually involving some, if not all, of the three most recently promoted clubs). Thirty-three clubs competed in the PL at some stage during the study period, with ten displaying permanency and a number of others reappearing (at least once) following demotion. Twelve teams achieved a top six position at least once, with the three teams that featured in all seven seasons also sharing the championship honours (Arsenal twice, Chelsea once, and Manchester United four times), and one other club (Liverpool) appearing in the top six on all but one occasion. ${ }^{4}$ In addition to a few ownership changes and, more commonly, managerial turnover (see Bridgewater, 2005) team composition underwent regular and often major restructuring, as players left and joined clubs, having usually been sold

\footnotetext{
${ }^{3}$ See, for example, Goddard (2006) and Szymanski (2006a) for a fuller treatment of association football in England and the economics of association football (soccer) respectively.

${ }^{4}$ This indication of competitive imbalance in English association football has been explicitly investigated by Michie and Oughton (2004). Employing a range of indicators, their study of English football over the period 1947-2004 shows that, while competitive balance in the top division remained roughly consistent between 1947 and 1987, there has been a significant decline since then particularly indicating a growing inequality between the top five clubs and the rest. See also Szymanski and Smith's (1997) pre-Premiership investigation of English association football, Dobson and Goddard's (1998) historical investigation of performance, revenue and cross-subsidization in the English FL, and Dobson et al.'s (2001) study of revenue convergence in the English FL. Michie and Oughton (2004) also identify similar trends in competitive balance experienced by two other top-flight European leagues in Germany and Italy, and to a lesser extent in France and Spain.
} 
or bought in the transfer market (see Carmichael (2006) and Frick (2007) for an examination of the transfer system and professional footballers' labour market). Another notable, if obvious, feature of the PL is that, like other sporting sectors, it is highly labour intensive. This is evident from the relatively high ratio of wage expenditure to revenue earned. For example, figures from Deloitte $(2006$, p. 16) indicate that wages as a percentage of turnover in the PL rose from 47 percent in the 1995-96 season to 59 percent in the 2004-5 season (after reaching a peak of 62 percent during the 1999-2000 and 2001-02 seasons).

\section{DATA SET AND EMPIRICAL MODEL}

The data used in our analysis of the PL originates from three main sources. The financial data on wage expenditure, club revenue and transfer spending is derived from Deloitte (annually 2000-2007). The data relating to playing performance and league success in the PL is obtained from two sources. Data for the 1998-9 to 2001-2 seasons was obtained from OPTA (1999-2002) while Actim data for the 2002-3 to 2004-5 seasons was accessed through PA Sports (2007). Playing performance data comprise match play statistics, in terms of goals, shots, saves, tackles, passes, etc. Club success data relate to end of season league positions, and points totals, while other variables cover management input/change, the home-field effect and participation in other competitions.

The empirical model consists of three behavioural equations:

$$
\begin{gathered}
S_{i t}=S\left(P_{i t}, M_{i t}, I_{i t}\right) \\
R_{i t}=R\left(S_{i t}, S_{i t-1}, M_{i t}, I_{i t}\right) \\
W_{i t}=W\left(P_{i t}, M_{i t}, I_{i t}\right)
\end{gathered}
$$

where the subscript $t$ indicates the $t$ th season $(t=1998-1999,2004-$ 2005) and subscript $i$ indicates the $i$ th club $(i=1,33) . R_{i t}$ is the $i$ th club's share of revenue earned within the league in the $t$ th season and $S_{i t}$ a measure of the $i$ th club's share of league success in $t . S_{i t-1}$ is a measure of the $i$ th club's share of league success in $t-1, W_{i t}$ measures relative wage expenditure by the $i$ th club (as a percentage share of total Premiership expenditure in $t$ ), $M_{i t}$ is a vector of managerial inputs, $P_{i t}$ is a vector of playing inputs reflecting playing skills and talent, and $I_{i t}$ is a vector of other inputs. Definitions of all variables and summary statistics are presented in Table 1 and the Appendix.

The vector of managerial inputs includes two measures: tenure in years at the current club at the start of the season (MANYRS) and whether 


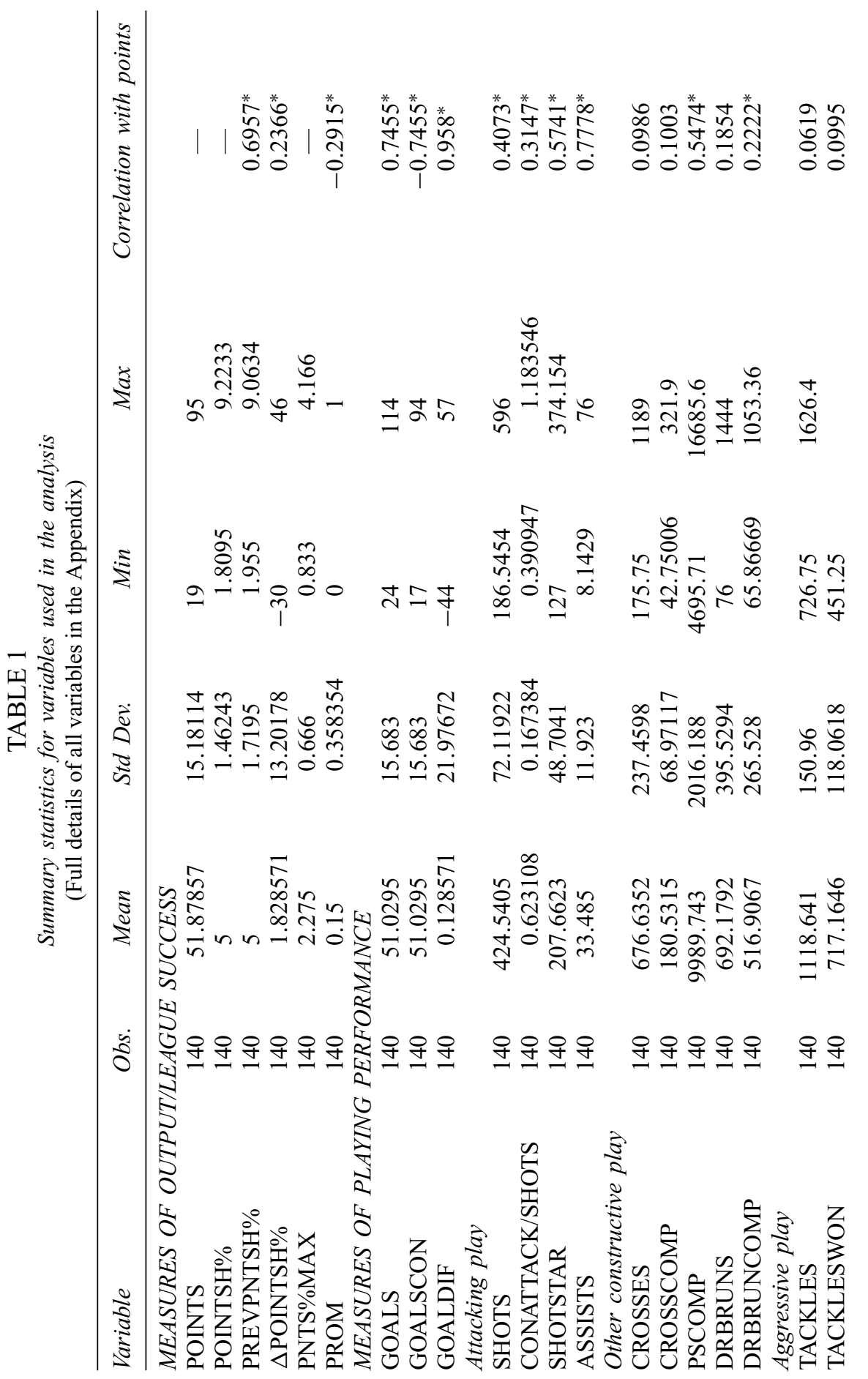

(C) 2010 The Authors. Bulletin of Economic Research

C 2010 Blackwell Publishing Ltd and the Board of Trustees of the Bulletin of Economic Research 


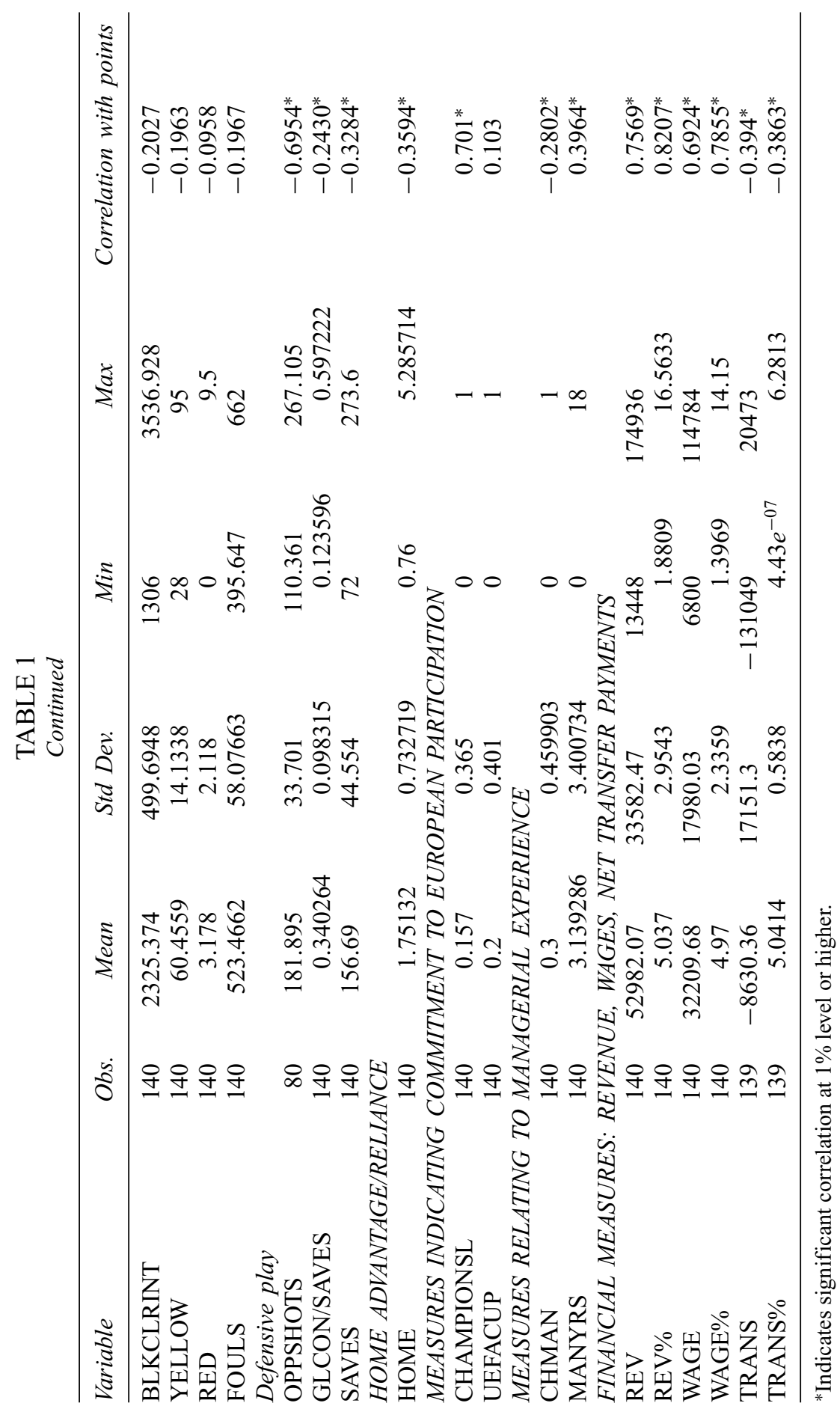

(C) 2010 The Authors. Bulletin of Economic Research

(C) 2010 Blackwell Publishing Ltd and the Board of Trustees of the Bulletin of Economic Research 
there was a managerial change in the current season (CHMAN). ${ }^{5}$ The vector of playing performance variables includes measures of a range of skills and abilities common to both the OPTA and Actim data. These capture various aspects of attacking play, other constructive play, less constructive play, aggressive play and defensive play (as detailed in Table 1 and the Appendix). The vector of other inputs includes a measure of reliance on home advantage, as the season ratio of points won at home to points won away (HOME). Additionally, dummy variables indicating participation in European competitions are included in the estimation of Equations (2) and (3).

Equation (1) is a sports' production function in which a club's output is measured by success in the league, $S_{i t}$, and depends on playing inputs, $P_{i t}$ (performances on the field), and non-playing inputs such as the managerial contribution and the strength of home support. $S_{i t}$ may be measured in a number of ways as noted earlier. However, since we are particularly interested in implications for competitive balance, we measure success in terms of the $i$ th club's percentage share of the total points achieved by all clubs during the season, POINTSH\%. The distribution of this measure of league success has been used in previous research to provide an indication of the degree of competitive balance since it is, in effect, the $i$ th club's (market) share of total output in the league (Michie and Oughton, 2004). ${ }^{6}$ An alternative measure of success is the $i$ th club's percentage share of the total points attainable by all clubs in any season, PNTS\%MAX, and for comparison we also estimate Equation (1) with this alternative dependent variable.

Equation (2) is a standard revenue equation in which revenue is a function of output and managerial specific inputs. In this case, club shares in total Premiership revenue, REVSH\%, are estimated as a function of the share of total output measured by playing success in the current and previous seasons (POINTSH\%, PREVPNTSH\% and PROM), where PREVPNTSH\% measures a club's share of points in the previous season and PROM indicates whether a club was promoted to the PL at the end of the previous season. Club revenue in the $t$ th season is derived mainly from match day attendance, membership packages, the sale of broadcasting rights and sponsorship deals, ${ }^{7}$ and at least the first two of these depend to a large extent on a club's recent success as well as historical, club-specific factors. For example, Szymanski and Kuypers

\footnotetext{
${ }^{5}$ See Audas et al.'s $(1999,2002)$ studies of managerial change in English association football.

${ }^{6}$ Michie and Oughton (2004) apply the C5 concentration ratio to the analysis of association football (total points won by the top five clubs divided by the total number of points won by all clubs) as an application of the standard industry measure.

${ }^{7}$ Data from Deloitte (2007) indicates that, in 2005-6, 33 percent of revenue in the PL was derived from match day attendance, 42 percent from broadcasting and 25 percent from sponsorship.
} 
(1999) found a strong, positive correlation between the revenue of 40 English football clubs and their league position between 1978 and 1997. In addition, while match day attendance is linked to league performance, broadcasting revenue from television rights is distributed in the current season partly on the basis of league performance in the previous season (so-called merit payments). Forrest et al. (2006) have also found that both broadcaster and audience demand for televised matches is related to the league success of teams in the previous season. Furthermore, Deloitte (2006) identify on-field performance as the 'key revenue driver' for clubs because it eventually provides access to lucrative European competitions. This consideration highlights the 'multi-product' commitment of the top clubs which (following Gerrard, 2006) is controlled for by including dummy variables indicating participation in the UEFA Champions League (CHAMPIONSL) and the UEFA Cup (UEFACUP). ${ }^{8}$

Equation (3) is a hedonic wage-price or earnings function that relates players' skills and performances to wage expenditure measured as a share of total Premiership wages in each season (WAGESH\%). ${ }^{9}$ This specification implies that the value of players to clubs depends ultimately on their playing performance which, in turn, is determined by their skills and ability (their human capital) as well as the contribution of the manager and complementary inputs.

Whereas (1)-(3) together constitute a recursive system of equations that can be estimated using ordinary least squares (OLS) (Kmenta, 1997, pp. 719-720), Equation (3) implies that wage expenditure is an indirect determinant of success (because wage expenditure purchases human capital). Thus playing success, and by implication revenue, depend on wage expenditure (as is suggested by previous research on the winwage relationship). However, wage expenditure will also depend to some extent on the availability of finance and the latter is determined at least in part by a club's revenue which is linked to success (as implied in Equation (2)). This suggests that there is potential simultaneity in the win-wage relationship (as also discussed in Gerrard, 2006) because random shocks that affect success and revenue probably also affect wage expenditure. ${ }^{10}$

\footnotetext{
${ }^{8}$ We are grateful to an anonymous referee for suggesting that we take account of the impact on wage costs and revenue of participation by the top clubs in pan-European competitions.

${ }^{9}$ In the absence of data on players' wages, transfer fees have been used in previous research to estimate hedonic earnings equations for individual players. As with earnings, transfer fees, where payable, should be determined by the (expected) playing performances of individual players. However, since the Bosman ruling, many players are transferred without a fee and when transfer fees are paid they are paid to the selling club rather than to the transferred player (see, for example, Antonioni and Cubbin, 2000; Ericson, 2000; Kesenne, 2006). The determination of transfer fees is therefore potentially more complex than that of wages since the former depends on the outcome of a transaction involving at least three participants the buying club, the selling club and the player - as well as the players' agent (see, for example, Carmichael, 2006; Frick, 2007).

${ }^{10}$ In addition, standard cost theory implies that total wage costs and output are jointly determined (particularly when there is limited scope for substitution between inputs).
} 
This is investigated by using the instrumented variable (IV) estimator to re-estimate Equation (1) treating wage expenditure as an endogenous regressor:

$$
S_{i t}=S\left(X_{i t}, W_{i t}\right)
$$

where $W_{i t}$ is instrumented by independent variables found to be significant in Equation (3), and $X_{i t}$ is a vector of exogenous performance, managerial and other inputs. The influence of wage expenditure on league success is further explored by additionally weighting WAGESH $\%$ by the inefficiency term from a stochastic wage-cost frontier estimation of Equation (3). A larger and more significant effect of the weighted variable compared with that of WAGESH\% would imply that wage expenditure over and above that of the estimated relationship between wages and playing skills and performances exerted a direct effect on performance. Such an effect would be consistent with a number of explanations, including playing skills and performances not captured in the hedonic wage estimation (such as superstar effects; see, for example, Lucifora and Simmons, 2003), efficiency wages or other, perhaps clubspecific, high-wage strategies (DeBrock et al., 2004).

Table 1 presents some summary statistics and definitions relating to the playing performance and financial variables in the data set, and also reports correlation coefficients between league points and the other variables. The data indicate that current season league success is positively correlated with previous performances (measured by the previous season's points and entry into the UEFA Champions League), revenue and wage costs as well as all the variables measuring attacking play, and with two of the variables measuring constructive play and managerial tenure. League success is not significantly correlated with measures of aggressive play but is negatively related to two defensive measures, a change of manager, reliance on home advantage, net transfer fees and whether a team has been newly promoted.

\section{RESULTS}

In this section, we report the results of our estimations of the production, revenue and hedonic wage equations (1)-(3). Initially, we report OLS estimations for each of the specifications. In addition, we estimated both panel data random and fixed effects models to examine the significance

However, the inclusion of the current season's wage expenditure in the production function is less problematic if wage contracts (like transfer fees) reflect only expectations (based on performances in previous seasons or with different clubs) rather than the actual contributions of individual players to current performance and revenue generation. Also, it seems unlikely that wage expenditures are completely unrelated to current performances (e.g. through performance related bonuses) even if previous performances are also relevant. 
of individual club effects. Because the random effects model is more efficient than the fixed effects model, the results from fitting the former are reported where the Breusch and Pagan Lagrange multiplier test indicated that the individual effects were significant and a Hausman test indicated that the model was consistent (Baum, 2006, pp. 220-231). The alternative fixed effects model is presented if a Hausman test indicated that the random effects model was not consistent and an $F$-test indicated that there were significant individual effects, implying that pooled OLS was inappropriate. In order to consider efficiency issues in relation to production and wage costs, we additionally fitted the stochastic frontier model to the production and wage functions (Equations (1) and (3)).

\section{V.1 Production}

Table 2 shows the results from estimating a production function for the PL with output measured by the natural log of POINTSH\% (and for comparison LnPNTS\%MAX) and inputs chosen to reflect a range of playing skills and performances. Among the independent variables we do not include any direct measures of goals scored or conceded even though goals are the only measures of playing performance that contribute directly to winning or losing in association football. While this means that the relationship between league points and goals is very strong (goal difference explains a little over 80 percent of the variation in league points) it is predictable, and the underlying performances that lead to the creation or concession of a goal are intrinsically more interesting. In essence, success depends on goals scored and conceded but goals themselves depend on other aspects of playing performance (Carmichael et al., 2001). We therefore experimented with a number of playing performance measures that were common to both data sources. However, the influences of some of the measures were not significant in a multivariate context.

From among those variables that were significant in various combinations we selected a number to reflect a range of performances and skills that included attacking play, other constructive play, aggressive play, defensive ability, managerial inputs and home advantage, and a process involving the elimination of the least significant variables led to the specification presented in Table 2 . For example, we initially included a number of raw quantitative measures of playing performance such as the total number of shots taken (those on target as well as those off target), the number of crosses made, the number of dribbles and runs, the number of yellow and red cards received (for a variety of infringements/disciplinary offences), the number of fouls committed, and the number of tackles made. However, more qualitative measures (when available) generally proved to be more successful than these raw measures. These included the following variables (for full definitions see the Appendix): a measure 


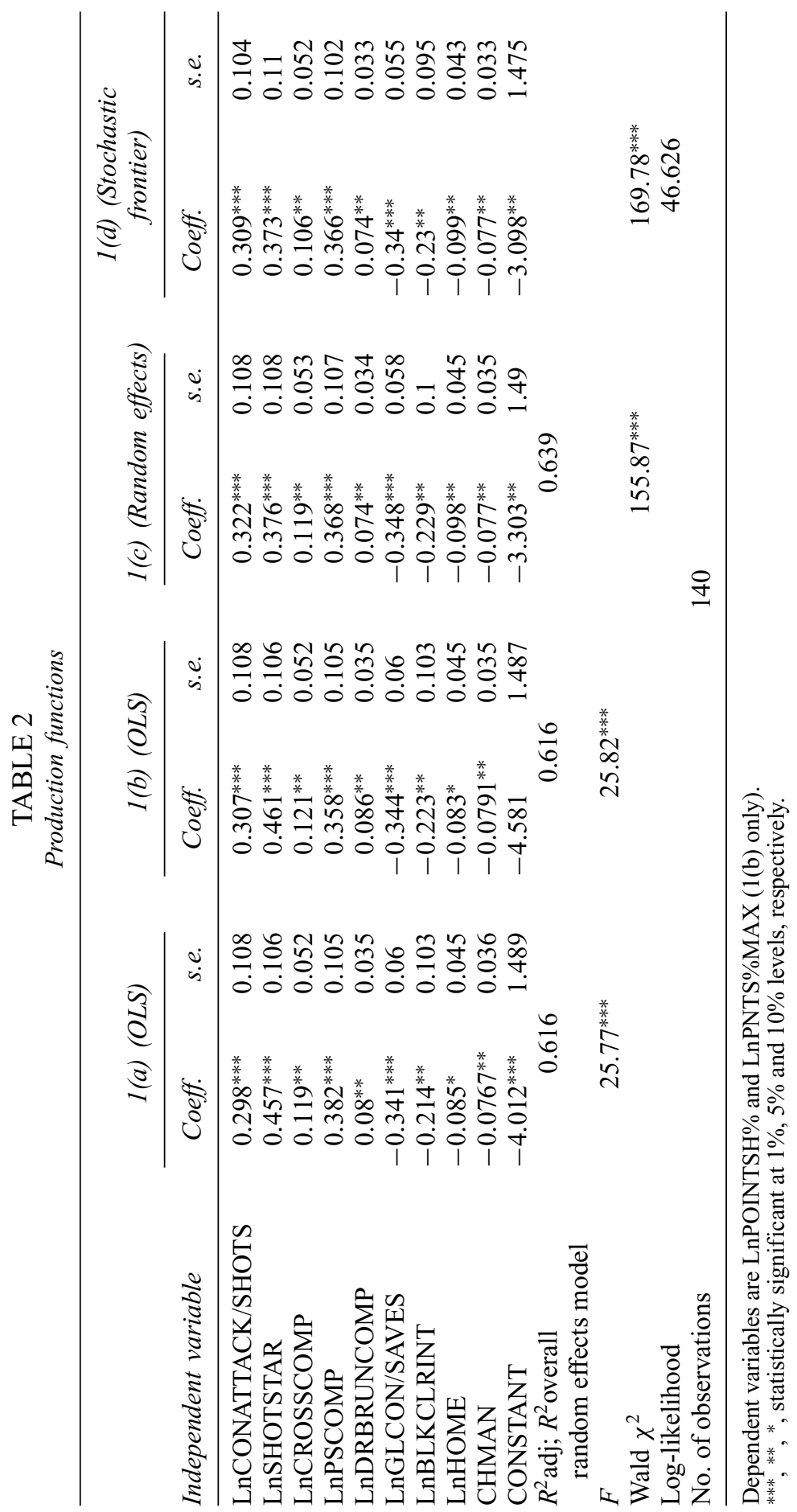

C) 2010 The Authors. Bulletin of Economic Research

C 2010 Blackwell Publishing Ltd and the Board of Trustees of the Bulletin of Economic Research 
of the constructiveness or efficiency of overall attacking play (the ratio of goals, assists and accurate shots to total shots; CONATTACK/SHOTS); a measure providing an indication of the quantity of effective attacking play (total shots on target; SHOTSTAR); three measures chosen to provide some indication of a team's ability to retain possession of the ball (the number of passes, crosses, and dribbles and runs actually completed; PSCOMP, CROSSCOMP and DRBRUNCOMP); and one (negative) measure of the quality of a team's defensive skills (the ratio of goals conceded to goalkeeper saves; GLCON/SAVES). Because a good defence should be able to reduce the effectiveness of the opposition's attack, and make a goalkeeper's task of saving shots at goal easier and/or more effective, fewer goals should be conceded. Therefore a negative sign on GLCON/SAVES is expected.

The results in Table 2 show that these constructed measures of performance take predictable signs in the estimations, and their greater significance compared with the equivalent raw measures appears to confirm the seemingly commonsense prediction that the quality of play or possession is a more influential determinant of success than the quantity of possession. Unfortunately, no completion data were systematically available for blocks, clearances or interceptions and therefore only the raw numerical measure (BLKCLRINT) could be included, taking a negative sign. Other measures relating to more aggressive play such as fouls committed and tackles, and red or yellow cards awarded, were never significant and are not included in the estimations presented. This lack of significance could be because the influence of aggressive play, such as tackles and interceptions, is difficult to predict a priori since it is not obvious whether such play is an indication of positive attacking play or more desperate play resulting from lack of possession. In fact, the negative influence of BLKCLRINT suggests that the latter is more likely to be the case. Of the two measures of managerial experience only the influence of CHMAN was ever significant. It takes a negative sign in the regressions, ${ }^{11}$ as does the measure of a team's reliance on their home advantage, which would indicate the limitations of an over-reliance on the home-field effect and the need for more balanced home and away performance.

The results presented are full log estimates of the exponential, CobbDouglas production function since specification tests suggested that the loglinear estimation was marginally better specified than the linear

\footnotetext{
${ }^{11}$ The negative influence of a managerial change is consistent with a negative impact of transition. However, managerial change is also potentially endogenous to these estimations (we are grateful to an anonymous referee for making this point). Changes often occur when a team performs poorly, although movements of managers within the PL indicate that managerial changes can also take place when a team is performing relatively well. With the inclusion of the managerial change variable in the estimations, the signs and influences of the other variables in the estimation were not significantly affected and since the managerial role is deemed to be relevant we report the results with this variable included.
} 
estimation. ${ }^{12}$ All the included variables are significant at the 10 percent level or higher and the logged formulation also provides a useful estimate of the overall returns to scale; the sum of the continuous coefficients is less than one (0.695) indicating diminishing returns overall although constant returns to scale could not be ruled out on the basis of a Wald test. The $R^{2}$ statistic suggests that around 62 percent of the variation in league performance is explained by the measures included in the regression.

A comparison of estimations 1(a) and 1(b) shows that there is little difference in these results when the dependent variable is PNTS\%MAX compared with POINTSH\%. Therefore, for consistency with the relative revenue and wage measures and the seasonal market share interpretation of $\mathrm{POINTSH} \%$, the latter is used in subsequent estimations. ${ }^{13}$

Estimation 1(c) takes into account the panel nature of the data by estimating a random effects model. ${ }^{14}$ We also used the fixed effects model to fit the equation but an $F$-test showed that the individual fixed effects were not significant. Because a Hausman test indicated that the random effects model was efficient only these results are presented. In this estimation all the included variables are significant at the 5 percent level or higher. The sum of the coefficients is also less $(0.583)$ but constant returns are only rejected at the 10 percent level of significance.

The lack of evidence for increasing returns to playing performance implies that improvements in performance only result in proportionate (or less than proportionate) increases in a club's share of league points. This suggests that competitive balance is not disproportionately threatened by improvements in the quality of play of more successful teams. Nevertheless one team's increase in the share of points must imply, by definition, a decrease in the share of another.

Estimation 1(d) is a stochastic frontier estimation of the CobbDouglas production function that incorporates the panel-specific effect in the random inefficiency term. In this estimation the inefficiency terms are significant at the 1 percent level and they can be used to rank the clubs on the basis of the efficiency of their performance over the seven study seasons (see Table 5 later). The estimates indicate that, of the 33 clubs, Everton and Chelsea were the most efficient at manufacturing points from playing performance. The least efficient teams were Manchester

\footnotetext{
${ }^{12}$ RESET and Link function tests failed to reject both specifications (as well as a semi-log estimation) at the 5 percent level of significance. However, the RESET test of the linear form rejected the assumption that the model was correctly specified at the 10 percent level of significance.

${ }^{13}$ However, as pointed out by an anonymous referee, using the POINTSH\% variable means that the measure of success will vary between seasons even if a club has exactly the same number of points but other teams have a different number of draws.

${ }^{14}$ We additionally estimated an OLS estimation including dummy variables (OLSDV) for 32 of the 33 clubs (equivalent to the fixed effects model). None of the club dummy variables were significant in the OLSDV estimation and a RESET test indicated that the model was not correctly specified.
} 
City and Crystal Palace, who presumably squandered more of their playing possession.

\section{V.2 Revenue}

Estimations 2(a) and 2(b) in Table 3 show the results of estimating a loglinear formulation of Equation (2). Clubs' share of total revenue is regressed on clubs' share of output in the current and preceding seasons, and the influences of both are shown to be positive and significant. PROM and LnMANYRS are also included in these estimations. The former is an alternative measure of success in the previous season and appears to have a positive impact on revenue shares, while the latter is included to capture the possible impact on club earnings of managerial experience although LnMANYRS is found to be insignificant and takes a negative sign. The coefficients of the continuous variables in the estimation sum to 1.893 and the assumption of constant returns to success is rejected in favour of increasing returns at the 5 percent level of significance. In estimation 2(b) the dummy variables controlling for participation in European competitions are included but only participation in the UEFA Champions League appears to have a significant effect on revenue shares. That the inclusion of CHAMPIONSL reduces the influence of a club's share of points in the preceding season is not altogether surprising since entry into the lucrative European competitions is dependent on previous league success. The reduced influence of promotion in the previous season is perhaps more interesting suggesting that, when the prior performance of the most successful clubs is allowed for, the relative impact of promotion is weaker.

Estimations 2(c) and 2(d) allow for club-specific fixed effects. These capture historical fixed effects associated with the core support and relative success and failure of individual Premiership clubs. The fixed effects are significant and a Hausman test indicates that the fixed effects model is preferred to the random effects model. Specification tests also indicated that, after allowing for club-specific fixed effects, the estimations were correctly specified. ${ }^{15}$

In estimation 2(c) the inclusion of fixed effects reduces the influence of current success and, as in estimation 2(b) with the inclusion of CHAMPIONSL and UEFACUP, the influence of previous season success and promotion is also reduced, although both measures remain significant at the 1 percent and 5 percent levels, respectively. This can be taken to imply that the club fixed effects capture sources of club revenue related to previous success (as do the European competition dummy variables).

\footnotetext{
${ }^{15}$ When club fixed effects were not included RESET and Link tests suggested that both the logged and linear formulations were incorrectly specified while the inclusion of fixed effects indicated that both were correctly specified. However, since a Wald test rules out constant returns to league success, the log version is preferred.
} 


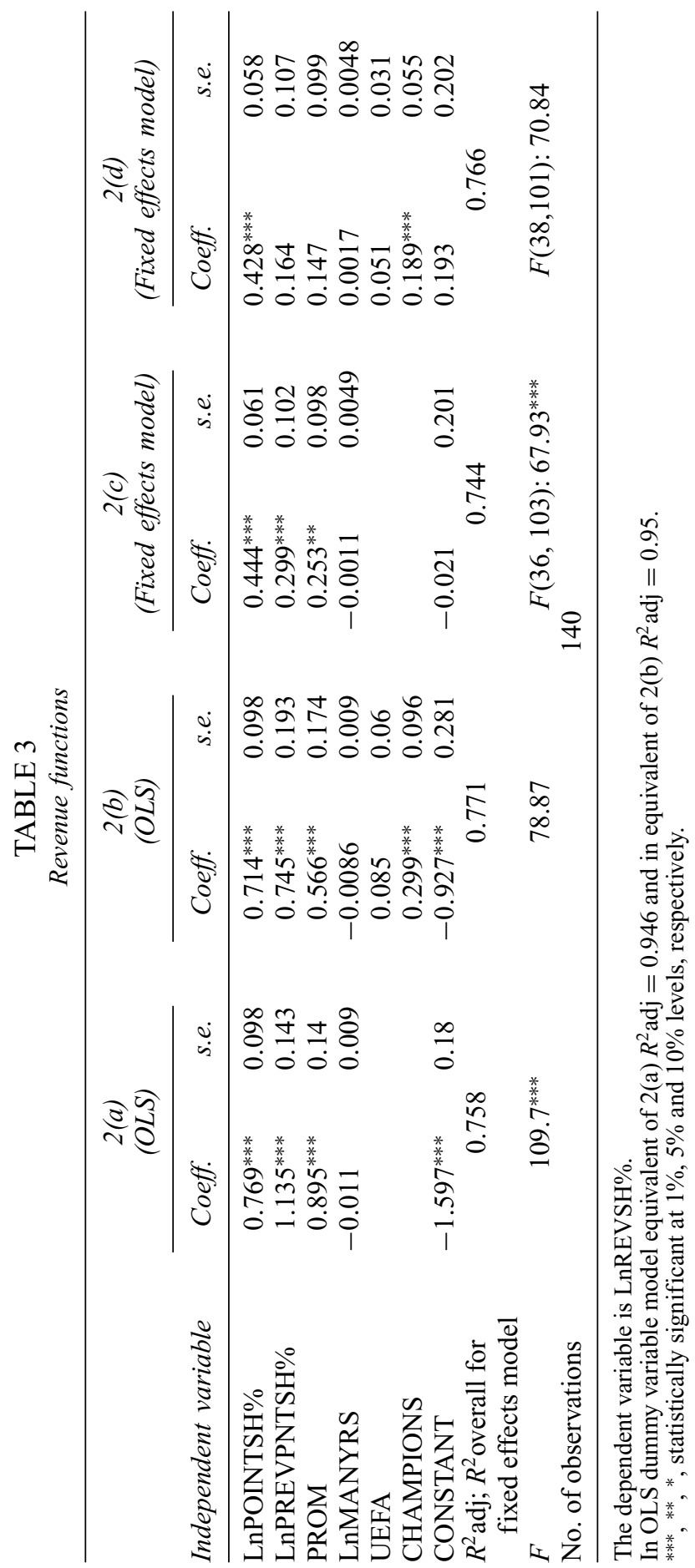


This interpretation is supported by the lack of significance of the measure of previous season's success and promotion in estimation 2(d) which includes the European competition dummy variables as well as the club fixed effects (although the influence of UEFACUP is not significant and the coefficient on CHAMPIONSL is reduced compared with estimation 2(b)). With the inclusion of the club-specific fixed effects in estimation 2(c) the sum of the coefficients of the continuous variables is only 0.727 and the assumption of constant returns is rejected in favour of diminishing returns at the 5 percent level of significance. In estimation 2(d) the sum of the coefficients of the continuous variables and the European competition variables is still less than one $(0.833)$ but the assumption of constant returns cannot be rejected by a Wald test.

The results suggest that after allowing for club effects and success in the preceding season the financial returns to success in the PL accumulate at a constant or diminishing rate. Since increasing returns to success are not implied by these results, this would appear to have positive implications for competitive balance. On the other hand, however, the evidence that club-specific effects impact on revenue shares independently of league success is likely to have negative implications for competitive balance. The significance of participation in the UEFA Champions League is also consistent with this interpretation, since in every season in the data set Arsenal and Manchester United and (except during 200001) either or both of Chelsea or Liverpool were also playing in that tournament. This suggests that some clubs have access to resources that are a source of sustained advantage in terms of their revenue earning ability (Barney, 1991). In the case of football clubs, these are most likely to have arisen from their individual and unique club histories, which will have endowed some clubs with more valuable resources than others. In estimations 2(c) and 2(d) the positively significant club fixed effects are those of Arsenal, Aston Villa, Chelsea, Leeds United, Liverpool, Manchester City, Manchester United, Newcastle United, Sunderland, Tottenham Hotspur and West Ham United. Even after allowing for their current season league performance and including any participation in the Champions League, these clubs earned significantly more than the other clubs in the sample throughout the period under investigation. Inasmuch as there is a causal link from revenue to league success via investments in players, this would appear to have adverse implications for competitive balance since it implies that some sources of revenue are unequally distributed and independent of league success.

Overall, the results indicate that there is a strong, significant relationship between revenue shares and current as well previous playing success (measured by clubs' shares in total points, success in achieving promotion and participation in European competitions). Nevertheless, the significance of the club-specific fixed effects implies that other sources of revenue are also important. 


\section{V.3 Hedonic wages}

Within the sample of PL clubs, 65 percent of revenue was spent on wages over the study period. Whether this expenditure reflected an accurate assessment of the value of the available playing talent was examined by estimating a hedonic wage-price function, or an earnings equation, for the PL. In the estimations reported in Table 4 the independent variables included to reflect players' skills and abilities are the same as those in the production function estimates presented in Table 2 with two exceptions. First, LnMANYRS is included rather than CHMAN because the influence of the latter was not significant in these estimations. Second, the European competition variables are included in estimation 3 (b). Inasmuch as the independent variables are significant then this can be interpreted as evidence that wages are an efficient payment for playing talent (as previous research indicates). This would have implications for competitive balance, since it would suggest that there is a positive link between wage expenditure and playing performance and ultimately financial success. Such a link is a necessary condition for the existence of virtuous (and vicious) circles in the English PL (Michie and Oughton, 2004) since these imply feedback effects via wage expenditure from playing and financial success (and failure) to future performances.

The $R^{2}$ statistic for estimation 3(a) indicates that measurable skills, a club's reliance on home advantage and managerial tenure explain 57 percent of the variation in wage costs. This result suggests that players are systematically rewarded for their skills and performance. In particular, clubs are willing to pay a premium for attacking skills (specifically constructive attacking possession including the ability to shoot on target). They also reward skills related to the ability to maintain possession of the ball and potentially create attacks (passing ability). In contrast, inefficient defensive play (conceding goals) is associated with a wage penalty implying that good defensive abilities attract a positive premium. Potentially less constructive, aggressive play, reflected in this estimation by blocks, clearances and interceptions, may be more difficult to value and this measure is not significantly related to wage expenditure. An over-reliance on home advantage is negatively related to wage expenditure as is club-specific managerial experience.

The sum of the continuous coefficients in specification 3(a) is 1.093 suggesting that wage costs rise a little more than proportionately in relation to players' skills and abilities. This would be consistent with a small 'superstar' wage effect since it would imply that very highly skilled players receive disproportionately higher wages (although constant costs were not rejected by a Wald test). Because clubs with more 'superstar' players are more likely to be involved in the European competitions this possibility is explored by including the dummy variables UEFACUP and CHAMPIONSL in estimation 3(b). In this estimation, participation in 


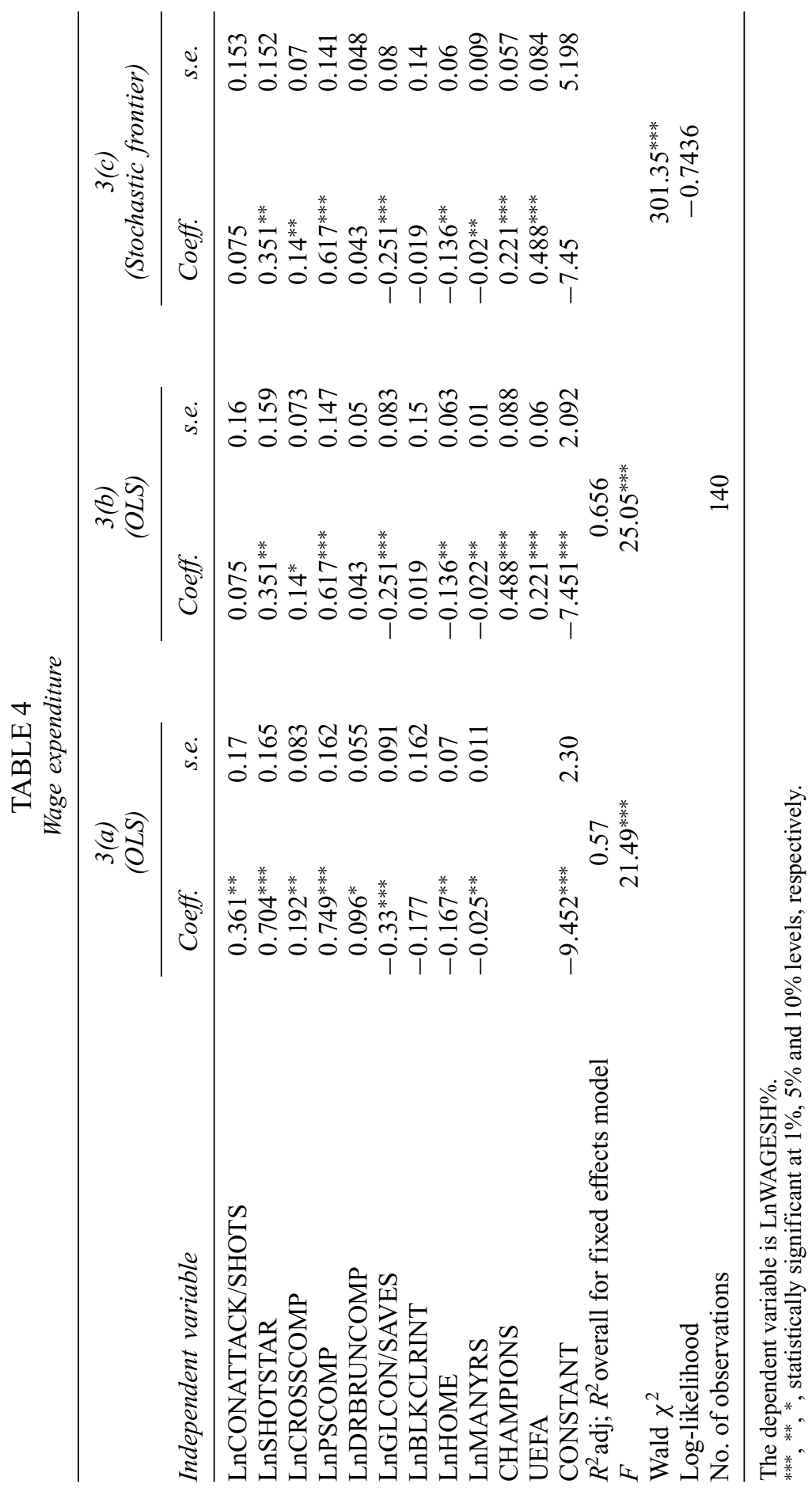

(C) 2010 The Authors. Bulletin of Economic Research

C 2010 Blackwell Publishing Ltd and the Board of Trustees of the Bulletin of Economic Research 
both European competitions exerts a significant and positive influences on wage expenditure and the influences of some of the playing performance variables are correspondingly reduced. With the inclusion of the European competition variables in estimation 3(b), around 9 percent more of the variation in wage expenditure is explained and the sum of the continuous coefficients is reduced to 0.836 . This suggests that, after allowing for European participation, wage costs rise, if anything, less than proportionately to playing skills and performances (although constant returns were not ruled out). This result is consistent with a significant proportion of the wage bill of the most successful clubs being a reward for player performances in competitions external to the English PL.

Table 4 does not present the results from either the fixed or random effects estimations. Tests indicated that the former were not significant and those of the random effects model not consistent, implying that pooled OLS was appropriate. However, estimation 3(c) shows the results from the stochastic frontier estimation of the hedonic wage function. The $u_{i}$ inefficiency terms from this estimation were used to construct the inefficiency (high wage) rankings in Table 5. Higher $u_{i}$ are indicative of a club pursuing a high or premium wage strategy that involves clubs incurring higher than minimum costs for playing talent, and in this sense only are they 'inefficient'. The highest and, arguably, the most 'inefficient' payers were Chelsea, Liverpool, Manchester United and Arsenal. Among these four teams only Arsenal and Chelsea were also among the six most efficient clubs at converting playing performances into league success (column 3).

\section{V.4 Success and wage strategies}

As has been noted, previous research has found a strong, positive correlation between success and wage expenditure. Szymanski and Kuypers (1999) and Hall et al. (2002) find very strong positive relationships between league position in English football and wage expenditure. These results have been interpreted as implying that clubs have good information about the talent of individual players and pay wages that reflect their productivity with reasonable accuracy, i.e., they get what they pay for. This is confirmed to some extent by the hedonic wage estimations. To examine the links between wage expenditure and playing performance explicitly we re-estimated Equation (1) as Equation (1.1). The re-estimations reported in specifications 1.1(a) and 1.1(b) of Table 6 are estimated using the IV estimator with wage expenditure treated as endogenous and instrumented by the independent variables significant in estimation 3(b). To satisfy the order condition CHMAN and LnBLKCLRINT, which were not significant in 3(a) but are significant in the production function estimations in Table 2, are included as exogenous 


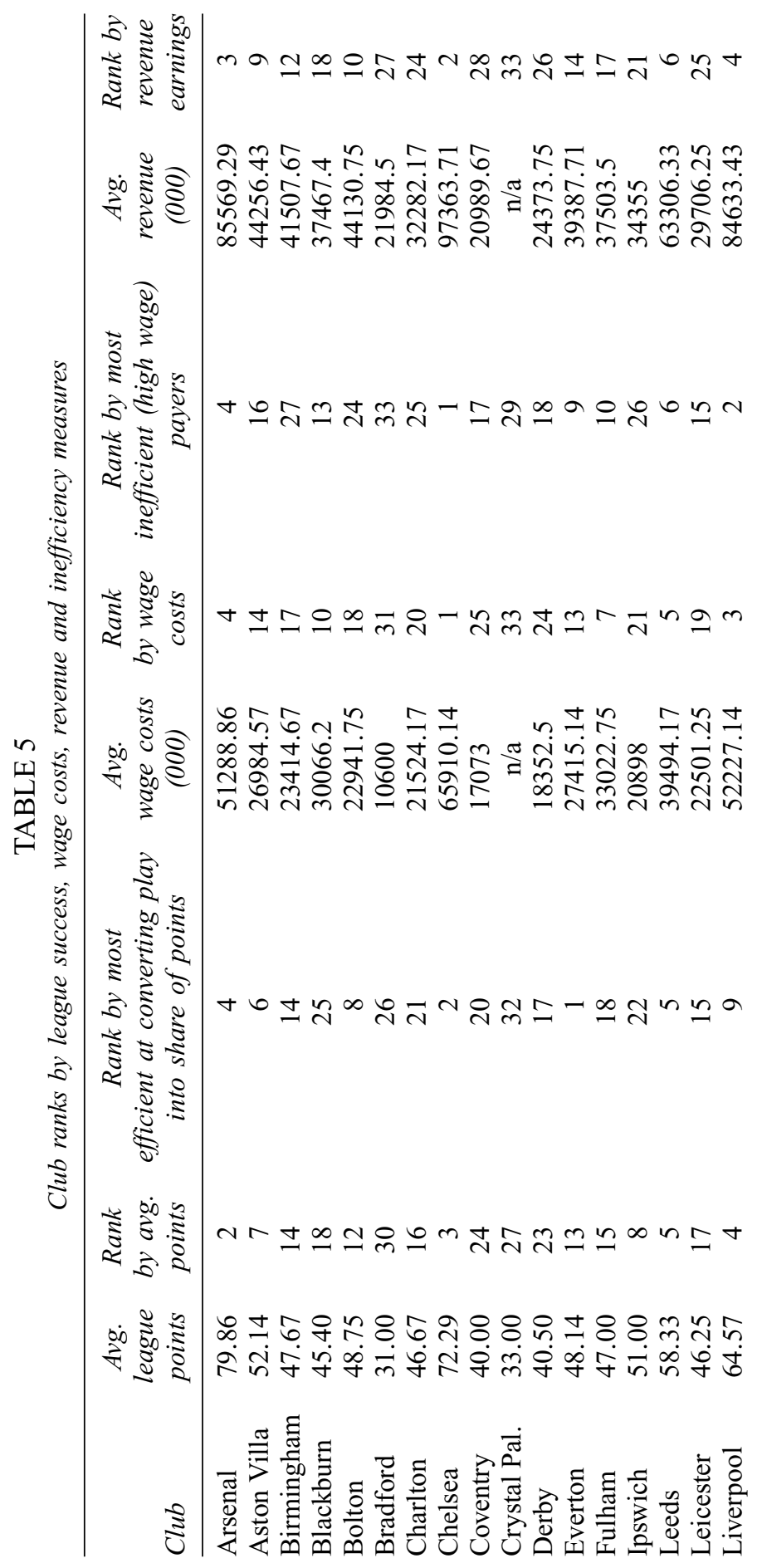

(C) 2010 The Authors. Bulletin of Economic Research

(C) 2010 Blackwell Publishing Ltd and the Board of Trustees of the Bulletin of Economic Research 


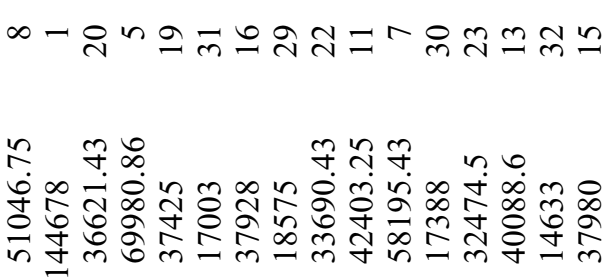

オmํำ

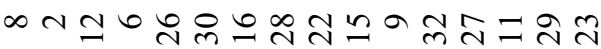

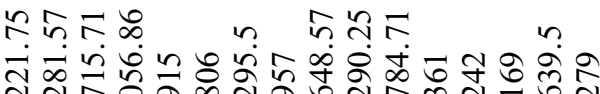

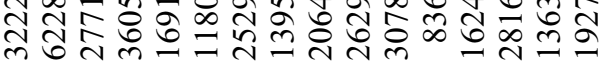

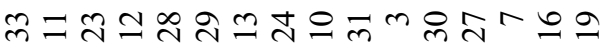

สー

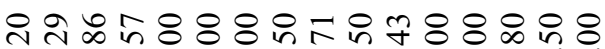

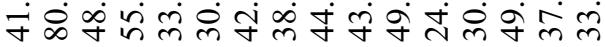

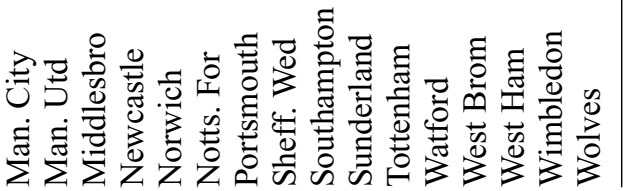

(C) 2010 The Authors. Bulletin of Economic Research

(C) 2010 Blackwell Publishing Ltd and the Board of Trustees of the Bulletin of Economic Research 


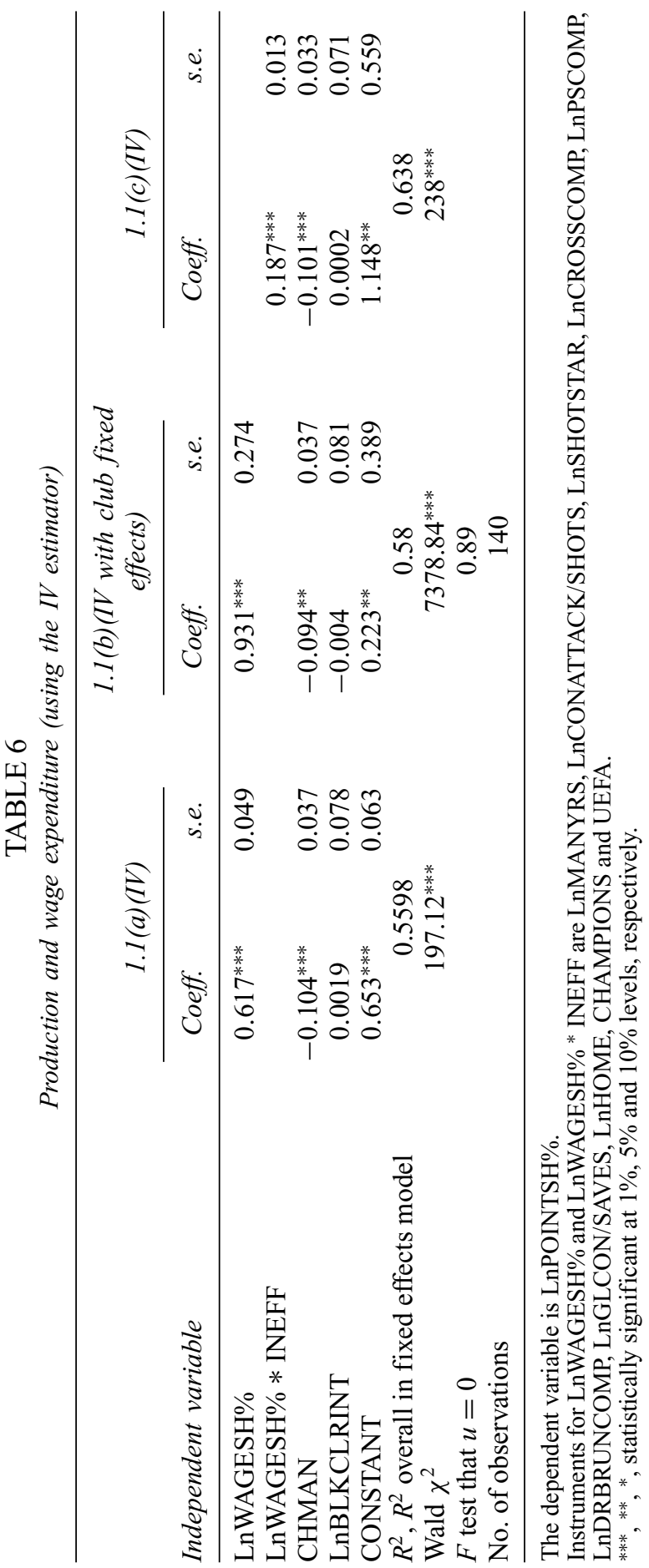

(C) 2010 The Authors. Bulletin of Economic Research

(C) 2010 Blackwell Publishing Ltd and the Board of Trustees of the Bulletin of Economic Research 
variables in these estimations. Sargan and Basmann tests for overidentifying restrictions in estimation 1.1(a) accepted the null hypothesis that the instruments were uncorrelated with the error term (Baum, 2006, pp. 193-194). Durbin-Wu-Hausman tests of endogeneity confirmed that it was appropriate to treat wage expenditure as an endogenous variable in the model (Baum, 2006, pp. 211-214).

Wage expenditure is significant in estimation 1.1(a), with the coefficient on LnWAGESH\% being 0.617. However, constant returns overall are rejected by the Wald test at the 1 percent level of significance, a significant result in that it suggests that the returns to wage expenditure in terms of the share of league points won are diminishing, and considerable increases in wage expenditure might therefore be needed to achieve a moderate improvement in league success. The $R^{2}$ statistic of 0.5598 is slightly lower than that for the production function estimations in Table 2 , suggesting that wage expenditure conveys considerable information about unmeasured skills and abilities of players. Additionally, wage expenditure may also reflect other influences on performance. For example, because we do not have data on the number of playing and non-playing staff, wage expenditure will also capture the influence of squad size and the contribution of non-playing staff. Interestingly, with the inclusion of club-specific fixed effects in estimation 1.1(b), wage expenditure retains significance but the $F$-test indicates that the club effects themselves are not significant. This suggests that the relationship between wage expenditure and success could be, in part, a club-specific one. ${ }^{16}$

To further explore the relationship between wage expenditure and playing success we include an alternative measure of wage expenditure in the IV specification 1.1(c). The variable LnWAGESH $\% *$ INEFF is equal to LnWAGESH $\%$ multiplied by the inefficiency term, $u_{i}$, derived from the stochastic cost frontier estimation of the hedonic wage function (estimation 3(c) in Table 4). Multiplying wage expenditure by the inefficiency term weights 'inefficient' spenders more highly. The somewhat greater significance of the instrumented multiplicative variable in estimation 1.1(c) and the higher $R^{2}$ indicates that clubs pursuing an 'inefficient' high wage policy are more successful, with one interpretation being that their higher wage costs are not an indication of inefficiency at all. In fact the opposite is implied, with the positive relationship between wage expenditure and league success being consistent with an 'efficiency' wage argument. ${ }^{17}$ A positive and significant correlation between the

\footnotetext{
${ }^{16}$ The RESET test indicated that estimation 1.1(a) was correctly specified. However, with the inclusion of club-specific fixed effects estimation 1.1(b) fails the RESET test at the 5 percent level of significance.

${ }^{17}$ Inasmuch as the efficiency wage interpretation is correct then performance depends directly on current wage expenditure, i.e., payment schemes are devised to give players incentives to improve their performances.
} 
inefficiency terms from the stochastic wage and production functions adds further support for this interpretation. There is therefore some suggestion that higher wage costs can be taken to reflect aspects of playing talent not measured by the available data (as implied in previous research).

\section{SUMMARY AND IMPLICATIONS}

The behavioural equations (1)-(3) can be interpreted as implying that there are feedback effects from current success on the field to future sporting success. These feedback effects are assumed to work by clubs ploughing back the revenue they earn from seasonal success into investments in playing skills, and these investments are in turn rewarded by further success. The estimations reported here for the English PL are consistent with such effects and, as such, and to the extent that clubs invest a substantial proportion of their increased revenue in player human capital, the investment policies of Premiership clubs generally appear to be successful. Wages can be systematically related to specific playing skills and the high wage strategies of some clubs can be linked to greater success on the field. These results are also consistent with cycles of relative success (and failure) in association football, where the underlying mechanism involves the ability of more successful clubs to invest in more human capital.

However, the implications of this for trends in competitive balance are less clear since the parameters of the estimated equations suggest that, after allowing for club-specific effects, club shares in league revenues are a diminishing function of their shares of league points. In addition, while constant costs in the production function and hedonic wage estimations are not ruled out, league success appears to be a diminishing function of wage expenditure. Therefore, even steep increases in wage expenditure could result in only moderate improvements in the share of league points won. On the other hand, the significance of club-specific effects and participation in European competitions in the revenue function implies that inequality of earnings is not simply a function of league performance. Some clubs have access to resources that are a source of sustained advantage, and as a consequence they are simply richer and their scope for investing in player human capital is accordingly greater.

To summarize, success on the field can be systematically linked to the skills and performance of players. Revenue is related positively to (current and previous) success on the field, and over 60 percent of revenue is spent on wages. Because wage bills systematically reflect the skills and performances of players, increased investment in playerrelated human capital buys success on the field (in the English PL and in European competitions). Successful teams become ever richer and are able to maintain or even build on their success by spending 
more on players than less successful clubs. To the extent that they are successful in this objective there is a causal link between revenue earned and competitive imbalance via investments in players. However, whether sustained success leads to increases in competitive imbalance rather than the maintenance of a status quo level of (im)balance remains to be established, although the parameters of the model estimated here suggest that the latter is more likely.

Our results for the PL may have wider implications relating to the evolution of firm size and market structure. The analysis can be thought of in terms of a field experiment (see Szymanski, 2001; or Kahn, 1993b) involving a market with a fixed number of 'firms' (although market membership varies by regular entry to and exit from the PL). In this view club shares in league points are analogous to market shares or, equivalently, firm size. The data here indicate that there is no automatic tendency for one firm (club) to become increasingly dominant, depending on the parameters of the model, but more successful clubs can remain so via a link between financial success and investment in players, although success in this respect is not guaranteed (as with any investment strategy). Nevertheless, by assuming that the number of firms (clubs) remains fixed, with no exogenous influences (other than those captured by the club-specific effects), the analysis ignores the possibility of a step change in industry structure, e.g., due to technological change. In relation to the English PL itself this omission is potentially serious. For example, while exogenous injections of cash (through, for example, ownership changes) into the dominant clubs can further cement competitive imbalances such cash injections can also change the circumstances of other clubs in the league dramatically. (In the latter context, and at the time of writing, we await the outcome of recent developments at Manchester City.)

The argument for maintaining competitive balance rests on the assumption that there are diminishing returns to increased concentration within a league. ${ }^{18}$ Clubs therefore need to exercise some self-restraint in relation to their investments in player human capital. This would be analogous to Nelson and Winter's (1977) view regarding the investment and output restraints exercised by firms that acquire substantial market

\footnotetext{
${ }^{18}$ While Kesenne (2004) distinguishes between 'good' and 'bad' types of competitive balance, Sanderson (2002) argues that competitive imbalance is an 'inherent' and 'intractable' part of all sporting competitions, and Zimbalist (2001) argues that competitive balance is an 'elusive' goal as long as players and club owners fight over the spoils. In addition to the specific references noted in fn. 4 , there is an abundance of studies treating the measurement of competitive balance and its implications in various sporting contexts, including Fort and Quirk (1997, 2004), Horowitz (1997), Kesenne (2000, 2004), Szymanski (2001, 2003a,b, 2006c), Hill and Fort (2002), Humphreys (2002), Zimbalist (2002, 2003), Bougheas and Downward (2003), Buzzachi et al. (2003), Fort and Maxcy (2003), Sanderson and Siegfried (2003), Bourg (2004), Szymanski and Kesenne (2004), Larsen et al. (2006), Crooker and Fenn (2007), Vrooman (2007).
} 
share, where a firm gaining a productivity advantage 'will not exploit this aggressively for fear of spoiling the market' (Nelson and Winter, 1977, p. 275). This would apply to a self-contained sporting league, with a fixed membership, whose general 'health' depends upon competitive balance and where the existence and survival of an individual club depends on the existence of others to compete with on a relatively equal basis. ${ }^{19}$ In such a situation of competitive balance, each club should aspire to be better than, but not that much better than, its rivals (Neale, 1964; El-Hodiri and Quirk, 1971) in order to ensure an appropriate level of outcome uncertainty in all its forms and at all levels, relating to individual match outcomes, season/tournament outcomes, and the lack of persistent longrun league domination by a single club or a small number of clubs. ${ }^{20}$ In the case of the English PL together with those of similar top-tier national leagues in Europe, however, the situation is rather different, in the sense that it is not self-contained but rather a vehicle through which clubs can secure participation in an additional, and more lucrative, continental market. In this context, the more successful clubs want to ensure that the gap between them and most, if not all, other clubs grows consistently and ever larger.

There is increasing evidence that the financial implications of such striving to maintain national market dominance, as well as simply retaining a position within a top-tier league, are causing major problems within the sport in England (Szymanski, 2006a) and throughout Europe (Lago et al., 2006; Szymanski, 2006b). ${ }^{21}$ Vrooman (2007) describes European football as being in a spiral of intra-league and inter-league polarization of talent and wealth with many, even leading, clubs having been driven to the edge of insolvency, and proposes a Super League combining clubs from the leading European footballing nations as a logical and necessary progression. To the extent that such a league would be fixed in composition and 'closed' to entry with no opportunity for advancement, the issue of equalization of team strengths would come to the fore, with competitive balance of concern to individual clubs as well as the league organization itself. However, this would arguably require new, or reintroduced or reformulated, regulations and constraints regarding matters such as salary caps, squad sizes, transfer markets and

\footnotetext{
${ }^{19}$ The question as to whether it is an individual club/team or the entire league which should be viewed as analogous to the firm has been the subject of a long standing debate in the literature on the economics of sport. See, for example, Neale (1964), Demmert (1973), together with Sloane's (1971) seminal work on the football club as a utility maximizer and various articles in Sloane (1997).

${ }^{20}$ See Borland and Macdonald (2003) and Szymanski (2003a, b, 2006c) for recent reviews of this literature.

${ }^{21}$ The increasing prevalence of financial 'distress' in English football is also addressed by Buraimo et al. (2006), amongst a symposium of articles published in the Journal of Sports Economics (vol. 7, no. 1) examining the individual circumstances of eight national leagues in Europe.
} 
player mobility, which Europe's major leagues have either relinquished or rejected and which are currently viewed as 'anathema' by the continent's leading clubs.

\section{REFERENCES}

Antonioni, P. and Cubbin, J. (2000). 'The Bosman ruling and the emergence of a single market in soccer talent', European Journal of Law and Economics, 9, pp. $157-73$.

Audas, R., Dobson, S. and Goddard, J. (1999). 'Organisational performance and managerial turnover', Managerial and Decision Economics, 20, pp. 305-18.

Audas, R., Dobson, S. and Goddard, J. (2002). 'The impact of managerial change on team performance in professional sports', Journal of Economics and Business, 54, pp. 633-50.

Barney, J. (1991). 'Firm resources and sustained competitive advantage', Journal of Management, 17, pp. 99-120.

Barros, C. P. and Leach, S. (2006a). 'Analyzing the performance of the English F. A. Premier League with an econometric function model', Journal of Sports Economics, 7, pp. 391-407.

Barros, C. P. and Leach, S. (2006b). 'Performance evaluation of the English Premier League with data envelopment analysis', Applied Economics, 38, pp. 1449-58.

Baum, C. F. (2006). An Introduction to Modern Econometrics Using Stata, College Station, TX: Stata Press.

Borland, J. (2006). 'Production functions for sporting teams', in Andreff, W. and Szymanski, S. (eds), Handbook of Sports Economics, London: Edward Elgar.

Borland, J. and Macdonald, R. (2003). 'The demand for sports', Oxford Review of Economic Policy, 19, pp. 478-502.

Bougheas, S. and Downward, P. (2003). 'The economics of professional sports leagues: some insights into the reform of transfer markets', Journal of Sports Economics, 4, pp. 87-107.

Bourg, J.-F. (2004). 'Professional team sports in Europe: which economic model?', in Fort, R. and Fizel, J. (eds), International Sports Economics Comparisons, Westport, CT, and London: Praeger.

Bridgewater, S. O. (2005). An Analysis of Football Management Trends 19922005 in All Four Divisions, Warwick: Warwick Business School.

Buraimo, B., Simmons, R. and Szymanski, S. (2006). 'English football', Journal of Sports Economics, 7, pp. 29-46.

Buzzachi, L., Szymanski, S. and Valleti, T. (2003). 'Equality of opportunity and equality of outcome: open leagues, closed leagues and competitive balance', Journal of Industry, Competition and Trade, 3, pp. 167-86.

Carmichael, F. (2006). 'The player transfer system in soccer', in Andreff, W. and Szymanski, S. (eds), Handbook of Sports Economics, London: Edward Elgar.

Carmichael, F. and Thomas, D. (2005). 'Home-field effect and team performance: evidence from English Premiership football', Journal of Sports Economics, 6, pp. 264-81.

Carmichael, F., Thomas, D. and Ward, R. (2000). 'Team performance: the case of English Premiership football', Managerial and Decision Economics, 21, pp. 31-45. 
Carmichael, F., Thomas, D. and Ward, R. (2001). 'Production and efficiency in association football', Journal of Sports Economics, 2, pp. 228-43.

Crooker, J. R. and Fenn, A. J. (2007). 'Sports leagues and parity when league parity generates fan enthusiasm', Journal of Sports Economics, 8, pp. 139-64.

Dawson, P. and Dobson, S. (2002). 'Managerial efficiency and human capital: an application to English association football', Managerial and Decision Economics, 23, pp. 471-86.

Dawson, P., Dobson, S. and Gerrard, B. (2000a). 'Estimating coaching efficiency in professional team sports: evidence from English association football', Scottish Journal of Political Economy, 47, pp. 399-421.

Dawson, P., Dobson, S. and Gerrard, B. (2000b). 'Stochastic frontiers and the temporal structure of managerial and coaching efficiency in English soccer', Journal of Sports Economics, 1, pp. 341-62.

DeBrock, L., Hendricks, W. and Koenker, R. (2004). 'The impact of salary distribution on firm-level outcomes in baseball', Journal of Sports Economics, 5, pp. 243-61.

Deloitte (2006). Annual Review of Football Finance, Manchester: Deloitte.

Deloitte (2007). Annual Review of Football Finance, Manchester: Deloitte.

Demmert, H. G. (1973). The Economics of Professional Team Sports, Lexington, MA: Lexington Books.

Dobson, S. and Goddard, J. (1998). 'Performance, revenue and cross subsidisation in the English football league', Economic History Review, 51, pp. 359-76.

Dobson, S. and Goddard, J. (2001). The Economics of Football, Cambridge: Cambridge University Press.

Dobson, S. and Goddard, J. (2004). 'Revenue divergence and competitive balance in a divisional sports league', Scottish Journal of Political Economy, 51, pp. 359-76.

Dobson, S., Goddard, J. and Ramlogan, C. (2001). 'Revenue convergence in the English soccer league', Journal of Sports Economics, 2, pp. 257-74.

Downward, P. and Dawson, P. (2000). The Economics of Professional Team Sports, London and New York: Routledge.

El-Hodiri, M. and Quirk, J. (1971). 'An economic model of a professional sports league', Journal of Political Economy, 79, pp. 1302-19.

Ericson, T. (2000). 'The Bosman case: effects of the abolition of the transfer fee', Journal of Sports Economics, 1, pp. 203-18.

Espitier-Escuer, M. and Garcia-Cebrian, L. I. (2004). 'Measuring the efficiency of Spanish First Division soccer teams', Journal of Sports Economics, 5, pp. 329-46.

Fizel, J. L. and D’Itri, M. P. (1997). 'Managerial efficiency, managerial succession and organizational performance', Managerial and Decision Economics, 18, pp. 295-308.

Forrest, D. and Simmons, R. (2004). 'Buying success: team performance and wage bills in US and European sports leagues', in Fort, R. and Fizel, J. (eds), International Sports Economics Comparisons, Westport, CT, and London: Praeger.

Forrest, D., Simmons, R. and Buraimo, B. (2006). 'Broadcaster and audience demand for Premier League football', in Jeanrenaud, C. and Késenne, S. (eds), The Economics of Sport and the Media, Cheltenham: Edward Elgar. 
Fort, R. and Maxcy, J. (2003). 'Competitive balance in sports leagues: an introduction', Journal of Sports Economics, 4, pp. 154-60.

Fort, R. and Quirk, J. (1997). 'Introducing a competitive environment into professional sports', in Hendricks, W. (ed.), Advances in the Economics of Sport, vol. 2, Greenwich, CT: JAI Press.

Fort, R. and Quirk, J. (2004). 'Owner objectives and competitive balance', Journal of Sports Economics, 5, pp. 20-32.

Frick, B. (2007). 'The football players' labour market: empirical evidence from the major European leagues', Scottish Journal of Political Economy, 54, pp. 442-6.

Gerrard, B. (2006). 'Analysing the win-wage relationship in sports leagues: evidence from the FA Premier League, 1997/98-2001/2', in Rodriguez, P., Kesenne, S. and Garcia, J. (eds), Sports Economics After Fifty Years: Essays in Honour of Simon Rottenberg, Oviedo, Spain: University of Oviedo.

Goddard, J. (2006). 'The economics of soccer', in Andreff, W. and Szymanski, S. (eds), Handbook of Sports Economics, London: Edward Elgar.

Hall, S., Szymanski, S. and Zimbalist, A. S. (2002). 'Testing causality between team performance and payroll: the cases of Major League Baseball and English soccer', Journal of Sports Economics, 3, pp. 149-68.

Hill, J. and Fort, J. (2002). 'Pitfalls to measuring competitive balance with Gini coefficients', Journal of Sports Economics, 3, pp. 367-73.

Hofler, R. A. and Payne, J. E. (1998). 'Measuring efficiency in the National Basketball Association', Economics Letters, 55, pp. 293-9.

Hofler, R. A. and Payne, J. E. (2006). 'Efficiency in the National Basketball Association: a stochastic frontier approach with panel data', Managerial and Decision Economics, 27, pp. 279-85.

Horowitz, I. (1997). 'The increasing competitive balance in Major League Baseball', Review of Industrial Organization, 12, pp. 373-87.

Humphreys, B. R. (2002). 'Alternative measures of competitive balance in sports leagues', Journal of Sports Economics, 3, pp. 133-48.

Jewell, R. T. and Molina, D. J. (2004). 'Productive efficiency and salary dispersion: the case of US Major League Baseball', Scottish Journal of Political Economy, 51, pp. 127-42.

Kahane, L. (2005). 'Production efficiency and discrimination hiring practices in the National Hockey League: a stochastic frontier approach', Review of Industrial Organization, 27, pp. 47-71.

Kahn, L. (1993a). 'Managerial quality, team success, and individual player performance in Major League Baseball', Industrial and Labour Relations Review, 46, pp. 531-47.

Kahn, L. (1993b). 'The sports business as a labor market laboratory', Journal of Economic Perspectives, 14, pp. 75-94.

Kesenne, S. (2000). 'Revenue sharing and competitive balance in professional team sports', Journal of Sports Economics, 1, pp. 56-65.

Kesenne, S. (2004). 'Competitive balance and revenue sharing', Journal of Sports Economics, 5, pp. 206-12.

Kesenne, S. (2006). 'The Bosman case and European football', in Andreff, W. and Szymanski, S. (eds), Handbook of Sports Economics, London: Edward Elgar.

Kmenta, J. (1997). Elements of Econometrics, 2nd edition, Ann Arbor, MI: University of Michigan Press. 
Lago, U., Simmons, R. and Szymanski, S. (2006). 'The financial crisis in European football: an introduction', Journal of Sports Economics, 7, pp. 3-12.

Larsen, A., Fenn, A. J. and Spenner, E. C. (2006). 'The impact of free agency and the salary cap on competitive balance in the National Football League', Journal of Sports Economics, 7, pp. 374-90.

Lucifora, C. and Simmons, R. (2003). 'Superstar effects in sport: evidence from Italian soccer', Journal of Sports Economics, 4, pp. 35-55.

Michie, J. and Oughton, C. (2004). 'Competitive balance in football: trends and effects', Research Paper 2004 No. 2, Football Governance Research Centre, Birkbeck: University of London.

Neale, W. C. (1964). 'The peculiar economics of professional sports', Quarterly Journal of Economics, 78, pp. 1-14.

Nelson, R. R. and Winter, S. G. (1977). 'Simulation of Schumpeterian competition', American Economic Review, 67, pp. 271-6.

OPTA (1999-2002). Football Yearbook, London: Carlton.

PA Sports (2007). www.pa-sport.com/en/actim/index.html.

Porter, R. and Scully, G. W. (1982). 'Measuring managerial efficiency: the case of baseball', Southern Economic Journal, 48, pp. 642-50.

Sanderson, A. R. (2002). 'The many dimensions of competitive balance', Journal of Sports Economics, 3, pp. 204-28.

Sanderson, A. R. and Siegfried, J. J. (2003). 'Thinking about competitive balance', Journal of Sports Economics, 4, pp. 225-79.

Scully, G. W. (1974). 'Pay and performance in Major League Baseball', American Economic Review, 64, pp. 915-30.

Scully, G. W. (1989). The Business of Major League Baseball, Chicago, IL: University of Chicago Press.

Scully, G. W. (1995). The Market Structure of Sports, Chicago, IL: University of Chicago Press.

Sloane, P. J. (1971). 'The economics of professional football: the football club as a utility maximiser', Scottish Journal of Political Economy, 8, pp. 121-46.

Sloane, P. J. (ed.) (1997). 'The economics of sport', Economic Affairs (Special Issue), 17(3), pp. 2-6.

Szymanski, S. (2001). 'Income inequality, competitive imbalance and the attractiveness of team sports: some evidence and a natural experiment from English soccer', Economic Journal, 111(February), pp. F59-F84.

Szymanski, S. (2003a). 'The economic design of sporting contests', Journal of Economic Literature, XLI(December), pp. 1137-87.

Szymanski, S. (2003b). 'Incentives and competitive balance', European Sport Management Quarterly, 3, pp. 11-30.

Szymanski, S. (2006a). 'Football in England', in Andreff, W. and Szymanski, S. (eds), Handbook of Sports Economics, London: Edward Elgar.

Szymanski, S. (2006b). 'The future of football in Europe', in Rodriguez, P., Kesenne, S. and Garico, J. (eds), Sports Economics After Fifty Years: Essays in Honour of Simon Rottenberg, Oviedo, Spain: University of Oviedo.

Szymanski, S. (2006c). 'Uncertainty of outcome, competitive balance and the theory of team sports', in Andreff, W. and Szymanski, S. (eds), Handbook of Sports Economics, London: Edward Elgar.

Szymanski, S. and Kesenne, S. (2004). 'Competitive balance and gate revenue sharing in team sports', Journal of Industrial Economics, 52, pp. 165-77. 
Szymanski, S. and Kuypers, T. (1999). Winners and Losers: The Business Strategy of Football, London: Viking Books.

Szymanski, S. and Smith, R. (1997). 'The English football industry: profit, performance and industrial structure', International Review of Applied Economics, 11 , pp. 135-53.

Vrooman, J. (2007). 'Theory of the beautiful game: the unification of European football', Scottish Journal of Political Economy, 54, pp. 314-54.

Zimbalist, A. S. (2001). 'Competitive balance in Major League Baseball', Milken Institute Review, 3, pp. 34-64.

Zimbalist, A. S. (2002). 'Competitive balance in sports leagues: an introduction', Journal of Sports Economics, 3, pp. 111-21.

Zimbalist, A. S. (2003). 'Competitive balance conundrums', Journal of Sports Economics, 4, pp. 161-3.

APPENDIX

Definitions of variables

\begin{tabular}{ll}
\hline Variable & \\
\hline POINTS & Pofinition \\
POINTSH\% & $\begin{array}{l}\text { Points won } \\
\text { total points won by all clubs in current season } \\
\text { Points won in previous season as a percentage share of } \\
\text { total points won by all clubs in previous season }\end{array}$ \\
PREVPNTSH\% & $\begin{array}{l}\text { Points won in current season as a percentage of total } \\
\text { maximum points attainable }\end{array}$ \\
PNTS\%MAX & Dummy variable indicating a promoted club \\
& Goals scored \\
PROM & Goals conceded \\
GOALS & Goal difference \\
GOALSCON & Total shot attempts on goal (shots off and on target) \\
GOALDIF & Ratio of the sum of goals scored, assists and shots on \\
SHOTS & target (highly constructive plays) to total shots \\
CONATTACK/SHOTS & Total shots on target \\
SHOTSTAR & Passes leading directly to a goal (goal assists) \\
ASSISTS & Total crosses made \\
CROSSES & Total crosses completed (received by own team player) \\
CROSSCOMP & Total passes completed (received by own team player) \\
PSCOMP & Total dribbles and runs \\
DRBRUNS & Total dribbles and runs completed (received by own \\
DRBRUNCOMP & team player prior to pass, cross or shot) \\
TACKLES & Total tackles made \\
TACKLESWON & Total tackles won \\
BLKCLRINT & Total blocks, clearances and interceptions \\
YELLOW & Yellow cards received for infringements \\
RED & Red cards received for infringements/indiscipline \\
FOULS & Total fouls committed (conceded) \\
&
\end{tabular}

(Continued) 
APPENDIX

Continued

\begin{tabular}{|c|c|}
\hline Variable & Definition \\
\hline OPPSHOTS & Total shots on goal by opposition teams \\
\hline GLCON/SAVES & Ratio of goals conceded to goalkeeper saves \\
\hline SAVES & Total saves made by goalkeeper \\
\hline HOME & $\begin{array}{l}\text { Ratio of points won at home to points won away (in } \\
\text { season) }\end{array}$ \\
\hline CHMAN & $\begin{array}{l}\text { Dummy variable indicating a change in manager in close } \\
\text { season or during season }\end{array}$ \\
\hline CHAMPIONSL & $\begin{array}{l}\text { Club competed in UEFA Champions League in current } \\
\text { season }\end{array}$ \\
\hline UEFACUP & Club competed in UEFA Cup in current season \\
\hline MANYRS & Number of years manager with club at start of season \\
\hline REV & Total annual revenue (turnover) \\
\hline REVSH\% & $\begin{array}{l}\text { Revenue as a percentage share of total revenue earned by } \\
\text { all clubs in season }\end{array}$ \\
\hline WAGE & Annual expenditure on wages and salaries \\
\hline WAGESH\% & $\begin{array}{l}\text { Annual expenditure on wages and salaries as a percentage } \\
\text { share of total wages and salary expenditure by all clubs } \\
\text { in season }\end{array}$ \\
\hline TRAN & $\begin{array}{l}\text { Annual net receipts from transfers (purchases recorded as } \\
\text { negative value) }\end{array}$ \\
\hline TRANSH $\%$ & $\begin{array}{l}\text { Net receipts from transfers as a percentage share of total } \\
\text { net transfer spending (sample minimum value of } \\
\text { TRANS added to all values) }\end{array}$ \\
\hline LnWAGESH\% & $\begin{array}{l}\text { LnWAGESH } \% \text { multiplied by the inefficiency term }\left(u_{i}\right) \\
\text { from stochastic cost frontier estimation of the hedonic } \\
\text { wage }\end{array}$ \\
\hline
\end{tabular}

Notes: 1 . In the reported results the prefix $\Delta$ indicates the variable is the difference between the value of the variable in $t$ and its value in $t-1$. The prefix $L n$ indicates that a variable is the natural $\log$ of the original variable; the prefix $\operatorname{Ln} \Delta$ indicates that a variable is the natural $\log$ of the value of the variable in $t$ divided by the value of the variable in $t-1$.

2 . The previous points' totals of promoted clubs were set equal to the average points won by the bottom placed (and relegated) clubs in the PL over the period (27.429).

3. Data relating to playing performance are sourced from OPTA and Actim (PA Sports, 2007). SHOTS is the sum of shots on target and shots off target. CONATTACK/SHOTS is constructed from the total figures for goals scored, goal assists, shots on target and total shots. GLCON/SAVES is the total number of goals conceded divided by the number of goalkeeper saves. The number of completed passes, dribbles and runs and tackles is reported directly in the Actim data and constructed from reported totals and reported completion rates in the OPTA data. All other performance variables are as reported in OPTA and Actim.

4. Data relating to revenue, wages and transfer receipts were sourced from Deloitte (2000)(2007). As far as possible, the data used were those most recently reported. At the time of writing these data remained incomplete for Bradford (1997-8 wage and transfer data) and Middlesbrough (2004-5 transfer data only). The data are reported as presented in Deloitte (2000)-(2007) including three observations that were reported for only 11 month accounting periods.

5. Data relating to league points and positions, European competitions and management experience and changes were obtained from various editions of the Rothmans Football Yearbooks and Sky Football Year Books. 